\title{
PENGGUNAAN MEDIA KUNCI DETERMINASI TERHADAP KETERAMPILAN PROSES SAINS SISWA PADA MATERI HEWAN DI SMA NEGERI 1 SINDANG
}

\author{
Lissa \\ Prodi Pendidikan Biologi Universitas Wiralodra \\ Kenshin_lissa86@yahoo.com
}

Citasi: Lissa. 2018. Penggunaan Media Kunci Determinasi Terhadap Keterampilan Proses Sains Siswa Pada Materi Hewan di SMA Negeri 1 Sindang. Mangifera Edu. Vol 2 (2). Hal 88-95

\begin{abstract}
ABSTRAK
Keterampilan proses sains siswa dalam proses pembelajaran masih kurang terlatih. Penggunaan media di proses pembelajaran menjadi salah satu faktor kurangnya keterampilan proses sains siswa. Penelitian ini bertujuan untuk mengetahui pengaruh penggunaan media kunci determinasi terhadap keterampilan proses sains siswa pada materi hewan kelas X MIPA di SMA Negeri 1 Sindang Indramayu. Jenis penelitian yang digunakan adalah metode kuantitatif dan desain penelitian yang digunakan adalah True Experimental Design dengan teknik statistik Uji Mann Withney. Populasi dalam penelitian ini adalah semua siswa kelas X SMA Negeri 1 Sindang Indramayu yang berjumlah 432 siswa, sampelnya adalah kelas X MIPA 1 berjumlah 40 siswa dan X MIPA 2 berjumlah 37 siswa dengan teknik sampling cluster random sampling. Instrumen yang digunakan essay dengan jumlah 5 butir. Setelah pengolahan dan analisis data, rata-rata skor keterampilan proses sains siswa di kelas dengan pembelajaran media kunci determinasi X MIPA 1 adalah 85,25> 77,68 kelas dengan pembelajaran media konvensional X MIPA 2 dan $Z_{\text {hitung }}=2,50 Z_{\text {table }}$ $(0,05)(77)=1,65$. Karena $Z_{\text {hitung }}>Z_{\text {table }}$ maka Ho ditolak. Artinya ada pengaruh penggunaan media kunci determinasi terhadap keterampilan proses sains siswa pada materi hewan kelas X MIPA SMA Negeri 1 Sindang 2016/2017.
\end{abstract}

Kata Kunci: Pembelajaran Media Kunci determinasi, Keterampilan Proses Sains, Materi Hewan.

\section{PENDAHULUAN}

Penyempurnaan kurikulum menjadi sebuah aroma baru bagi dunia pendidikan. Kurikulum diciptakan untuk meningkatkan potensi siswa. Undang-Undang Nomor 20 Tahun 2003 tentang Sistem Pendidikan Nasional menyebutkan bahwa kurikulum adalah seperangkat rencana dan pengaturan mengenai tujuan, isi, dan bahan pelajaran serta cara yang digunakan sebagai pedoman penyelenggeraan kegiatan pembelajaran untuk mencapai tujuan pendidikan tertentu (Luzyawati, 2015:25). Dalam kurikulum 2013 revisi pengembangan proses pembelajaran sepenuhnya diarahkan sesuai Standar Kompetensi Lulusan yang mencakup ranah sikap, pengetahuan dan keterampilan. Oleh karena itu, 
dibutuhkan berbagai strategi pembelajaran baik itu pendekatan, model, metode maupun media yang mampu membantu siswa memenuhi ketiga ranah tersebut.

Pada hakikatnya IPA terbentuk atas kemampuan proses, produk dan sikap ilmiah. Proses belajar IPA menekankan terhadap keterampilan proses karena IPA pada umumnya dipandang sebagai suatu ilmu yang menekankan proses menemukan dan melahirkan pengetahuan serta sistematis dalam menerapkan metode ilmiah. Keterampilan proses sains merupakan karakteristik dari pembelajaran IPA dalam mengobservasi, menemukan konsep dan memecahkan masalah. Biologi merupakan bagian dari Ilmu Pengetahuan Alam (IPA) yang menyediakan berbagai pengalaman belajar kepada siswa untuk memahami konsep dan proses sains yang dilakukan dengan cara mencari tahu tentang alam secara sistematis (Silvilia, Efrina. S, 2015:695).

Berdasarkan observasi lapangan pada guru mata pelajaran biologi di SMA/MA Kabupaten Indramayu dapat disimpulkan bahwa pembelajaran biologi masih fokus terhadap ranah penguasaan materi dan pembelajaran teacher centered learning. Fakta lapangan membuktikan keterampilan proses sains siswa dalam pembelajaran kurang terstimulus. Pengajar cenderung menekankan pada tingkat pengetahuan saja. Hal ini menyebabkan keterampilan proses sains siswa tidak terlatih. Keterampilan siswa yang belum begitu terlatih diantaranya keterampilan dalam mengobservasi, mengklsifikasikan, mengkomunikasikan dan menyimpulkan. Keterampilan-keterampilan dasar tersebut seharusnya sudah dapat mereka kuasai namun menjadi hal yang tidak biasa dilakukan. Padahal keterampilan tersebut merupakan karakteristik dari pembelajaran IPA itu sendiri. Keterampilan ini hendaknya sudah terlatih bagi siswa, khususnya bagi siswa pada kejuruan MIPA di jenjang Sekolah Menengah Atas (SMA).

Keterampilan proses sains siswa juga berhubungan dengan tingkat motivasi dan keaktifan siswa yang dapat distimulus melalui media ajar. Ketidaktepatan pemilihan media pembelajaran dengan isi materi menjadikan kurang terdorongnya siswa untuk mempelajari materi sehingga siswa berlaku pasif dalam pembelajaran. Dengan begitu akan membuat siswa mudah mencerna mentah-mentah berbagai informasi secara instan, serta siswa tidak mendapatkan bekal kemampuan dalam melanjutkan pendidikan ke Perguruan tinggi. Permasalahan pada pembelajaran konvensional dapat diatasi dengan penerapan pembelajaran inovatif (Ambarsari,dkk. 2013:82). Pembelajaran inovatif merupakan pembelajaran yang mampu menarik minat siswa dan melibatkan siswa aktif didalamnya. Diantaranya dengan menggunakan media pembelajaran. Penggunaan kunci determinasi sebagai media dalam pembelajaran biologi menjadi alternatif dan solusi untuk meningkatkan 
keterampilan proses sains siswa dan menjadikan pembelajaran tersebut lebih bermakna. Karena dalam pembelajarannya siswa tidak hanya dituntut untuk mendengarkan dan menghafal, melainkan siswa diberikan ruang aktif untuk mampu memahami pengetahuannya secara mandiri, menemukan konsep secara mandiri dan membentuk keterampilan sosial. Penggunaan media kunci determinasi sendiri memberikan bekal pada siswa dalam mempersiapkan keilmuan pada jenjang pendidikan perguruan tinggi. Penelitian inibertujuanuntukmengetahuipengaruh media kunci determinasi terhadap keterampilan proses sains siswa pada Materi Hewan Di SMA Negeri 1 Sindang

\section{METODE PENELITIAN}

Penelitian ini dilaksanakan di SMA Negeri 1 Sindang pada semester genap tahun pelajaran 2016/2017. Penelitian ini merupakan penelitian Kuantitatif. Desain penelitian menggunakan posttest-only control design. Kelompok eksperimen menggunakan media kunci determinasi sedangkan pada kelas control menggunakan media konvensional yaitu lembar petunjuk praktikum.

Populasi dalam penelitian ini adalah siswa kelas X SMA Negeri 1 Sindang.Penarikan sampelditentukan dengan cara cluster random sampling. Hasil sampel menetapkan kelas $\mathrm{X}$ MIPA 1 sebagai kelas eksperimen dan kelas X MIPA 2 sebagai kelas kontrol.

Variabel bebas pada penelitian ini adalah media kunci determinasi dan variable terikat adalah keterampilan proses sains yang meliputi ranah kognitif dan psikomotorik. Teknik pengumpulan data dengan menggunakan tes essai dengan lima butir pertanyaan untuk mengukur kemampuan kognitif dan teknik observasi sebagai data sekunder digunakan untuk mengukur psikomotorik dan keterlaksanaan pembelajaran.

Tes uji coba instrument penelitian dilakukan untuk mengetahui validitas dan reliabilita ssoal. Validitas isi butir soal dan lembar observasi dilakukan oleh Dosen ahli. Analisis data pada penelitian ini menggunakan Uji U Mann Withney, dengan Prasyarat analisis yaitu Uji Normalitas menggunakan uji Chi-Square dilakukan sebelum analisis data.

\section{HASIL DAN PEMBAHASAN}

Hasil analisis pengaruh media kunci determinasi terhadap keterampilan proses sains siswa pada Materi Hewan Kelas X MIPA SMA Negeri 1 Sindang Tahun 2016/2017dapat dilihat pada Tabel 1.

Tabel 1. Hasil Uji U Mann Withney Dua Kelas Penelitia

\begin{tabular}{|l|l|l|l|l|}
\hline Kelas & Varians & Rerata & $\mathbf{Z}_{\text {hitung }}$ & $\mathbf{Z}_{\text {tabel (0.05)(77) }}$ \\
\\
https://journal.unwir.ac.id/index.php/mangiferaedu $\mid 73$
\end{tabular}




\begin{tabular}{|l|c|c|c|c|}
\hline $\begin{array}{l}\text { Kelas media pembelajaran } \\
\text { menggukan kunci determinasi }\end{array}$ & 199,47 & 85,25 & \multirow{2}{*}{2,50} & \multirow{2}{*}{1,645} \\
\cline { 1 - 4 } $\begin{array}{l}\text { Kelas menggunakan media } \\
\text { pembelajaran konvensional }\end{array}$ & 157,45 & 77,68 & \\
\hline
\end{tabular}

Berdasarkan Tabel 1 menunjukan hasil perhitungan uji u mann withney dengan menggunakan rumus $\mathrm{Z}$ dikarenakan jumlah $\mathrm{N}>20$, diperoleh hasil $\mathrm{Z}_{\mathrm{hitung}}=2.50$ dengan taraf signifikan $(0,05)(77) \quad Z_{\text {tabel }}=1,645$. Karena $Z_{\text {hitung }}>Z_{\text {tabel }}$ maka berdasarkan kriteria uji hipotesis dapat dinyatakan bahwa Ho ditolak. Artinya terdapat pengaruh media kunci determinasi terhadap keterampilan proses sains siswa pada materi hewan kelas X MIPA SMA Negeri 1 Sindang Tahun 2016/2017. Perbedaan kedua kelas ini dapat dilihat melalui perbedaan kedua rerata kelas yang digambarkan dalam gambar diagram batang dibawah ini.

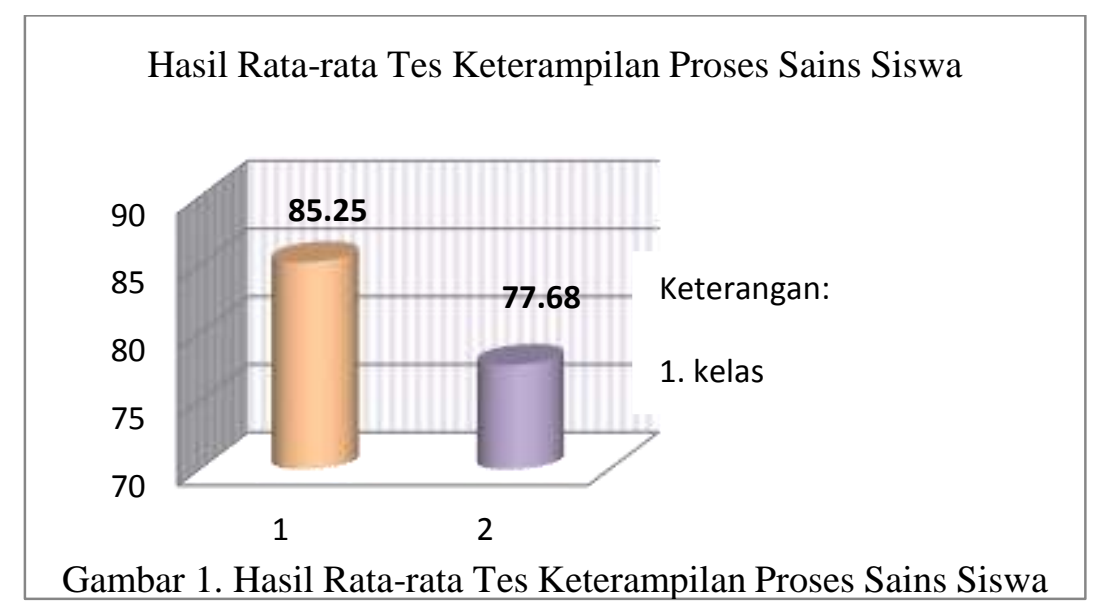

Berdasarkan gambar diagram batang 1. Terlihat perbedaan kedua rerata kelas eksperimen dengan skor 85.25 dan kelas kontrol 77.68. perbedaan tersebut dikarenakan pada saat proses pembelajaran kelas yang menggunakan media pembelajaran kunci determinasi siswa begitu sangat aktif dan termotivasi dalam mengikuti proses pembelajaran serta mampu memanfaatkan lingkungan belajarnya. Menurut Idha (2002) dikutip oleh suryoatmojo (2011:26) keterlibatan siswa dan pemberian motivasi akan memudahkan siswa dalam memahami konsep biologi secara mendalam. Pembelajaran yang aktif ini disebabkan juga karena media kunci determinasi melatih keterampilan ketelitian siswadan daya penalaran siswa dalam menentukan konsep cirri individu dengan benar. Diperkuat oleh pendapat Watson \& Miller (2009) yang dikutip dalam Purnamasari (2012:104) menyatakan bahwa penggunaan kunci determinasi dalam pembelajaran memiliki keunggulan karena mengembangkan daya kreativitas dan penalaran siswa, memotivasi siswa untuk belajar dan memudahkan siswa memahami, membandingkan dan menganalisis materi yang sedang dipelajari. Sejalan dengan hasil penelitian Adikusoma Suryoatmojo (2011), menunjukkan 
secara keseluruhan $88.1 \%$ siswa telah tuntas belajar materi klasifikasi tumbuhan. Hal ini menunjukan bahwa penggunaan kunci determinasi memiliki pengaruh positif terhadap aktivitas siswa, ketuntasan pembelajaran dan motivasi siswa. Hasil penelitian lain dilakukan Niken Kusumarini, dkk. (2012) penggunaan kunci determinasi bergambar dengan penerapan model STAD menunjukan bahwa penggunaan kunci determinasi efektif gunakan pada materi tumbuhan di SMA.

Sedangkan pada kelas menggunakan media pembelajaran konvensional siswa kurang mampu dalam menyelesaikan soal keterampilan proses sains. Perlakuan siswa tersebut dapat didukung dengan data hasil observasi proses pembelajaran. Hal ini disebabkan siswa kurang terlatih dalam menggali informasi secara mandiri dan karena media pembelajaran yang tidak menuntut siswa terlibat langsung dalam pembelajaran. Salah satunya adalah pada indikator klasifikasi, siswa tidak diberikan kesempatan untuk membandingkan atau menemukan cirri pada objek yang diamati. Media konvensional (petunjuk praktikum) hanya membantu dalam mengorganisasikan siswa melakukan penelitian dan hanya digunakan sebagai tuntunan agar siswa terarah dalam melakukan praktikum tidak. Sejalan dengan pendapat Mayhandoko (2013:12) bahwa petunjuk praktikum merupakan bagian dari bahan ajar tertulis.

Indikator keterampilan proses sains siswa dalam pemebelajaran ini mencakup indikato rmengobservasi, mengklasifikasi, mengkomunikasi dan menyimpulkan. Perbandingan rerata indikator dari kedua kelas sampel dapat dilihat pada gambar diagram batang 2 .

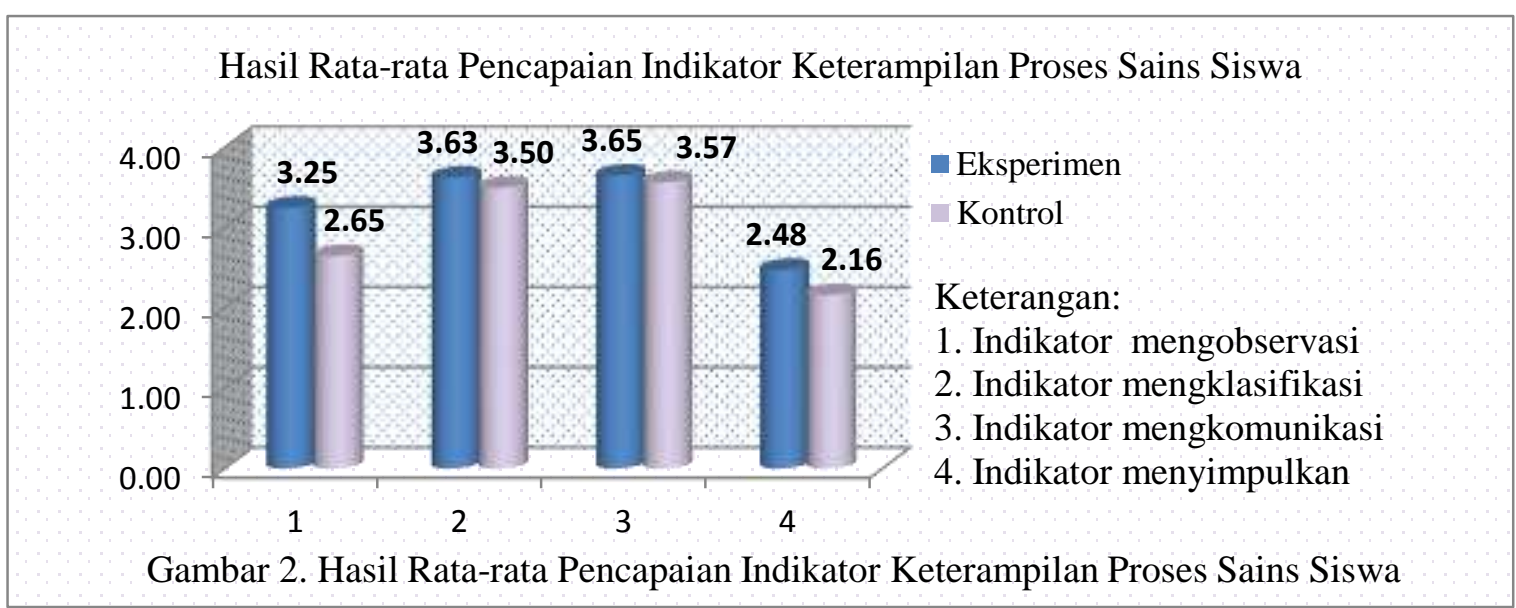

Berdasarkan gambar 2. Kelas eksperimen memiliki skor rerata yang lebih baik pada setiap indikator keterampilan proses sains siswa dibandingkan dengan skor rerata setiap indikator pada kelas kontrol. Hal ini dikarenakan dalam penggunaan kunci determinasi sebagai media pembelajaran dalam biologi, siswa tidak hanya mengira-ngira fakta dan 
konsep yang mereka ketahui saja, tetapi mereka juga diajak untuk membuktikan sendiri setiap cirri dikotom yang telah dibuat dalam kunci determinasi pada objek yang mereka amati dengan melakukan pengamatan secara morfologi maupun anatomi. Diperkuat oleh Ariyanti (2008:02) belajar biolog itidak cukup hanya dengan menghafal fakta dan konsep yang sudah jadi, tetapi dituntut pula untuk menemukan fakta-fakta dan konsep-konsep tersebut melalui observasi dan eksperimen. Dengan melakukan pengamatan secara morfologi dan anatomi, membantu siswa dalam melatih keterampilan mengobservasi siswa. Dimana menurut Nuryani (2004) yang dikuti poleh Purnamasari (2012:20) Keterampilan mengobservasi diartikan sebagai keterampilan proses dalam menggunakan kelima indra serta menggunakan fakta yang relevan dan memadai dari hasil pengamatan.

Selain mengobservasi dan mengklasifikasi, penggunaan kunci determinasi juga mampu meningkatkan kemampuan mengkomunikasikan dan menyimpulkan siswa. Kemampuan mengkomunikasi siswa diartikan sebagai kemampuan keterampilan proses siswa dalam menyajikan suatu data dari bentuk satu dalam bentuk lain. Menurut Aryanti (2008:08) karakter khusus dari keterampilan proses sains berkomunikasi adalah harus ada suatu bentuk pernyataan tertentu untuk diubah kebentuk penyajian lainnya. Dalam kunci determinasi siswa disajikan runtutan pernyataan berupa ciri yang saling berlawanan tanpa adanya suatu deskripsi, oleh karenanya siswa dirangsang untuk menggabungkan satu cirri dengan ciri lain untuk mampu mendeskripsikan objek nyata yang mereka amati dalam bentuk kalimat baik lisan dalam berdiskusi maupun tulisan dalam menjawab pertanyaan. Sedangkan kemampuan menyimpulkan diartikan sebagai kemampuan keterampilan proses dalam menemukan garis besar untuk menginterpretasikan suatu konsep berdasarkan pengetahuan yang dimiliki dan dari hasil pengamatan. Untuk menarik kesimpulan dalam suatu pengamatan dibutuhkan berbagai pengetahuan yang memadai.

Hal inidi karenakan kemampuan menyimpulkan tidak hanya mengenai apa yang diamati tapi apa yang telah diketahui (Purnamasari, 2012:18). Kunci determinasi memberikan kemudahan bagi siswa untuk mampu menaraik dasar pengelompokan hewan dengan mudah, dikarenakan pembuatan kunci determinasi berdasarkan pada perbedaan yang umum menuju perbedaan yang lebih khusus. Hal ini akan membantu siswa dalam menarik kesimpulan dasar pengelompokan makhluk hidup, oleh karenanya meskipun hasil indikato rmenyimpulkan tes KPS pada kelas yang menggunakan media kunci determinasi sama rendahnya dengan kelas menggunakan media konvensional, tetapi kelas yang menggunakan media kunci determinasi memiliki cukup selisi lebih baik dalam membuat kesimpulan disbanding dengan kelas yang menggunakan media konvensional. 


\section{KESIMPULAN}

Berdasarkan hasil penelitian dan analisis data yang telah dilakukan maka dapat disimpulkan bahwa media pembelajaran kunci determinasi berpengaruh terhadap keterampilan proses sains siswa pada materi hewan kelas X MIPA SMA Neeri 1 Sindang Indramayu Tahun 2016/2017.

\section{DAFTAR PUSTAKA}

Ambarsari, wiwin. dkk. 2013. The Application Of Guided Inquiry Approach To Basic Science Process Skills Of Students In Grade VIII Junior High School 7 Surakarta. (Jurnal Pendidikan Biologi Vol.5. No.1 (1) 2013. 81:95) Tersedia [online]. Diakses pada 04 Januari 2017. http://jurnal. fkip. uns. ac.id/index.php/bio/article/view/1441/1022.

Ariyanti, Eka, dkk. 2008. Evaluasi Pendidikan IPA. Bandung. Universitas Pendidikan Indonesia.

Kusumarin Niken, dkk. 2012. Efektivitas Kunci Determinasi Bergambar Dengan Penerapan Model STAD Pada Materi Plantae di SMA N 1 Suruh.(Unnes Journal of Biology Education Vol. 1 (1) (2012). 20-25. ISSN 2252-6579).

Luzyawati, Lesy. 2015. PENGANTAR ANALISIS KONTEN PEDAGOGI (implementasi analisis buku teks sesuai kurikulum nasional). Indramayu. Program Studi Pendidikan Biologi Fakultas Keguruan Dan Ilmu Pendidikan Universitas Wiralodra.

Mayhandoko, Adityas. 2013. Pengembangan Petunjuk Praktikum Kontekstual dengan Pemanfaatan Kondisi Lingkungan Lokal Dalam Pembelajaran Materi Pencemaran Di SMA N 2 Rembang. Skripsi. Semarang:Jurusan Biologi Fakultas Matematika dan Ilmu Pengetahuan Alam Universitas Negeri Semarang.

Purnamasari, Herni, dkk. 2012. Kunci Determinasi Dan Flashcard Sebagai Media Pembelajaran Inkuiri Klasifikasi Makhluk Hidup SMP. (Unnes Science Education Journal. Nomor 1 Vol. (2). 2012. 104:110).ISSN 22526617. diakses pada tanggal 15 Desember 2016. Tersedia [online]. http:// journal. unnes.ac.id/sju/index.php/usej.

Silvilia. Efrina S. 2015. Kelayakan Teoretis Lks Invertebrata Tanah Dengan Pendekatan Ilmiah Pada Materi Dunia Hewan Kelas X. ISSN: 2302-9528. (Jurnal Bioedu Berkala Ilmiah Pendidikan Biologi. Vol.4 No.1 (1). 2015. 684:699).

Suryoatmojo, Adikusoma. 2011. Efektifitas Penggunaan Kunci Determinasi Dengan Pendekatan Jelajah Alam Sekitar Pada Pembelajaran Klasifikasi Tumbuhan Di SMP Negeri 4 Temanggung. Skripsi, Jurusan Biologi FMIPA Universitas Negeri Semarang. 